\title{
Parasitic Cause of Organ and Carcass Condemnation in Small Ruminant Slaughtered at Helmex Abattoir, Debrezeit, Ethiopia
}

\author{
Mohammed Hussen, Said Hussen, Gebeyow Chali and Mukarim Abdurahaman \\ School of Veterinary Medicine, College of Agriculture and Veterinary Medicine (JUCAVM), Jimma \\ University, Jimma Town, Ethiopia
}

\begin{abstract}
The study was under take from November 2007 to April 2008 at Debrezeit, HELMEX Abattoir. The aim of this study was to identity and determines the parasitic cause of organ and carcass condemnation and to estimate the magnitude of the direct economic losses attributed to the condemned organs and carcasses from sheep and goats slaughtered in the abattoir. Standard ante mortem and post mortem inspection procedure were followed throughout the study period. A total of 140 small ruminants were inspected for ante mortem in the lair age and abnormalities encountered were recorded. In addition to this post mortem examination was also conducted on 589 animals to detect parasitic causes that rendered each organ and carcass to reject from local and international market. During the study period the total of 1536 small ruminates organs and carcasses were examined and revealed that 377(24.5\%)liver, 197(12.8) lungs, 15 (0.97\%) hearts, ,0(0\%), kidney and 0(0\%) carcasses were rejected due to parasitic causes: Fasciolosis (10.28\%), Hydrated cyst (9.75\%), Cysticercus tenuicollis (13.51\%), Stellesia hepatica (21.34\%), lung worm (19.78\%), and Cysticercus Ovis (0.97\%) were found to be the parasitic causes responsible for the rejection of respective organs . From the total organs inspected $38.34 \%$ organs of sheep and goats were rejected from the market and the annual losses due to the rejection of organs from small ruminants slaughtered in the abattoir is estimated to be 47272.5 USD. Finally conclusions are drawn and recommendations are forwarded:
\end{abstract}

Keywords: Monitory loss, Organ condemnation, small ruminants

\section{INTRODUCTION}

Ethiopian owns about 24 million sheep and 18 million goats (LMA, 2001). Sheep and goats cover more than $30 \%$ of all domestic meat, edible organ and skin (Fletcher and Zelalem, 1991). An increase in small ruminants production could contribute to the attainment of food self sufficiency for the growing human population as well as to enhances export earnings. However, this great livestock potential is not properly exploited traditional management methods limited genetic potential, government polices and rampant diseases mortality inferior weight gain, condemnation of edible organs and carcass at slaughter. This production loss to the livestock industry is estimated at more than 900 millions USD annually (Jacob, 1997, Abebe, 1995, Jobber et al., 1996).

It is necessary to be aware of the extent to which the public is exposed to certain zoonotic diseases detected in abattoir and the financial losses that incur through condemnation of affected organ and carcass (Nit and Alonge, 1987). As meat is the main sources of protein it should be free from zoonotic diseases like Hydatidosis, Cysticercosis' (Sirank, 1991).

Similarly like many other tropical African countries it is well known that the parasitic diseases are among the major factor for the low productivity of livestock in Ethiopia (Jobre et al, 1996: Abebe 1995).

Some parasitic diseases of food producing animals are zoonotic and veterinarian have a vital role in ensuring that these diseases are controlled in animal herds so that spread to human population does not occur (Radostits et al., 1994). It has been suggested that government or other program to control or eradicated diseases across Africa and to be monitored taking as a references the information obtained from abattoir (Alonge and Fasamni, 1979).

Export abattoir including HELMIX, ELFORA, Metahara, Modjo and Luna export abattoirs have been established in Eastern Showa Zone of Oromia Region, Ethiopia to export red meat and edible offal to 
international market. This enhances the economic development of the country through economical exploitation of the livestock base of the country (Jibat, 2006).

Various investigation have been conducted through abattoir survey to determine the prevalence of diseases and economic losses in which incurred due to condemnation of organs and carcass in Ethiopia (Jembere, 2002; Yimam, 2003; Assefa, 2005). However, most of the survey paid more attention to parasitic causes in cattle. Hence, there are particularly nonexpendable and precise information available with regards to small ruminants.

In view of this, proper evaluation of economic loss due to organs and carcass condemnation in sheep and goats at abattoir is needed. Therefore, the present study was under taken with the following objectives

- To identify the parasitic causes of organ and carcass condemnation of sheep and goats slaughtered at HELMEX abattoir.

- To estimate the magnitude of direct economic loss attributed to the condemned organs and carcass.

\section{Materials AND Methods}

\subsection{Study Area}

The study was conducted at Hashim abattoir, Debre Zeit from November 2007 to April 2008. The abattoir is privately owned abattoir exporting mutton, lamb, goat meat and edible organ like liver, kidneys and brain of sheep and goat to Middle East countries.

The abattoir is found in the Debre Zeit town, which is located at $9 \mathrm{~N}^{0}$ and $40^{\circ} \mathrm{E}$ with altitude of 1880 meter above sea level in the central highland of Ethiopia $47 \mathrm{~km}$ south east of Addis Ababa. It has annual rainfall of $1151.6 \mathrm{~mm}$ of which $84 \%$ fall down during the long rainy season that extends from March to May. The mean annual minimum and maximum temperature are $8.5^{\circ} \mathrm{C}$ and $30.7^{\circ} \mathrm{C}$ respectively, and the mean annual minimum and maximum humidity is $61.3 \%$ (NMSA, 2003). The animals originate from different part of the country with different agro- ecological zones: high land and low land. These areas are Arsi, Bale, Afar, East, Showa, Ogaden, Wallo, Omo and Borena.

The abattoir has holding pens in each of these region purchased animals are congregated in the holding pens before being transport to the abattoir by vehicle and on foot. The holding pens are found in Negele bornea, Yabello, Awasa, Wonji and Awash.

\subsection{Study Animals}

A total of 1536 animals (equal sheep and goats) destined for slaughter was inspected. The study was performed on edible organs (liver, lungs heart and kidneys) and carcass in both sheep and goats. The animal were grouped in to young (under one year of age in goat and one year and three month in sheep), and adult based on eruption of one or more incisor teeth according to (Gatenby, 1993 and Steele, 1996).

\subsection{Study Design}

The study type is cross sectional, lungs, liver, kidney, heart and carcass of both sheep and goats are selected randomly as presented for postmortem inspection and inspected.

\subsection{Sample Size}

Sample size was determined according to the formula, proposed by Thrusfied (1995) as indicated below.

$$
\mathrm{N}=\frac{1.96^{2} \operatorname{pexp}(1-\mathrm{pexp})}{\mathrm{d}^{2}}
$$

Where $\mathrm{n}=$ required sample size

Pexp $=$ expected prevalence $(50 \%)$

$\mathrm{D}=$ desired absolute precision $(5 \%)$

at $95 \%$ Confidence interval 
$\mathrm{N}=\underline{1.96^{2} \times 0.5(1-0.5)}$

$(0.05)^{2}$

$\mathrm{N}=384$ for each groups

One group consists of 384 animals were taken in this study to calculate the sample size within each group i.e 384 for each of the four group was summed up to give the total sample size of 1536- sheep and goats.

\subsection{Study Methodology}

\subsubsection{Ante Mortem Examination}

The animals were examined on both sides for their behavior, posture, conformation, gait and any discharges encountered with in twenty four hours of slaughtering. The animals with poor body condition, depressed, staring hair coat, and nasal discharge were slaughtered under special follow up during post mortem examination

\subsubsection{Postmortem Examination}

During meat inspection liver, lungs, heart, a kidneys and carcasses were thoroughly examined by visual inspection, palpation and making systematic incision, where necessary for the presences of cysts, adult parasites and other abnormalities. Pathological lesion was differentiated and judged based on (FAO, 1994) guideline on meat to developing countries.

\subsubsection{Assessment of Direct Economic Loss}

All affected organs and carcasses were condemned to enhance the international market; partial approval is not practiced in the abattoir. In assessing the economic loss, only the direct economic loss due to rejection of the organ and carcass from international market was considered. The analysis was based on annual slaughter capacity of the abattoir, average market prices of organ on the international market and Debre Zeit town and rejection rate of specific organ and carcass. The annual slaughter rate was estimated from retrospective market price of each organ and carcass was determined from interview made with personnel of the abattoir marketing department. Information obtained was subjected to mathematical computation by modifying the formula suggested by (Ogurinade and Ogurinade, 1980) for liver rejection.

$\mathrm{EL}=\sum$ Srxcoy $\mathrm{x}$ Roz

Where, EL= estimated annual economic loss due to organ carcass condemnation from international domestic market.

$\sum=$ Summation

Srx = Annual sheep/ goats slaughter of the abattoir

Coy $=$ Average cost of each sheep/goats liver/lung/heart/carcass

Roz $=$ Condemnation rates of sheep/goats, liver/lung heart/kidney/carcass.

\subsection{Data Management and Statistical Analysis}

Data generated from post mortem meat inspection was recorded in the Microsoft excel 2000 program (annex 1).

Description statistic such as percentage was used to determine the level of organ and a carcass condemnation rate which was define as the proportion of condemned organ and carcass to the total number of organ and carcass examined. The variation between condemnation rate of specific organ and carcass, age group differences were statistically evaluated for significant $\mathrm{p}$ - value less than 0.05 using STATA 7.0 (2001).

\section{RESUlT}

\subsection{Abattoir Survey}

\subsubsection{Ant mortem Examination}

The abnormalities found during conducting ante mortem inspection out of the total 1536 animals (equal sheep and goats) are 58(7.5\%) sheep and 82(10.6\%) goats (table). Nasal discharge was the 
highest abnormality detected in sheep (5.6\%) and (7.85\%) goats under gone ante mortem examination at HELMEX abattoir. However these animals were posses for slaughter with precaution of through post mortem examination as judged by the meat inspectors.

Table1. Abnormalities Encountered During Ante Mortem Examination

\begin{tabular}{|l|l|l|l|l|l|l|l|}
\hline Abnormalities & Sheep & \multicolumn{3}{l}{ Goats } & Total \\
\hline Condition & Young & Adult & Total & Young & Adult & Total & \\
\hline Lameness & $0(0)$ & $2(0.07)$ & $2(0.07)$ & $1(0.03)$ & $2(0.07)$ & 3 & $3(0.01)$ \\
\hline Poor Condition & $3(0.01)$ & $4(0.14)$ & $2(0.24)$ & $6(0.21)$ & $4(0.14)$ & 10 & $10(0.35)$ \\
\hline Local Swelling & $6(0.21)$ & $3(0.10)$ & $9(0.31)$ & $7(0.25)$ & $6(0.21)$ & 13 & $13(0.46)$ \\
\hline Nasal Discharge & $11(0.91)$ & $29(1.03)$ & $40(0.42)$ & $19(0.67)$ & $37(1.32)$ & 56 & $56(1.99)$ \\
\hline Total & $20(0.71$ & $38(1,34)$ & $58(2.05)$ & $33(1.16)$ & $49(1.75)$ & 82 & $82(2.99)$ \\
\hline
\end{tabular}

\subsubsection{Postmortem Examination}

Out of 1536 animals (sheep and goats) slaughtered, 377(24.5), 197(12.8\%), 15(0.97\%) $0(0)$ and $0(0 \%)$ of liver, lung heart, kidney and carcass were condemned from gross abnormalities as unit for international and domestic

Market Significances differences was observed in condemnation rates among organs $(\mathrm{P}<0.05)($ Table2)

Table2. Organs/Carcass Condemnation rates of sheep and goats

\begin{tabular}{|l|l|l|l|l|l|l|}
\hline Animal Species & No of animal Examined & \multicolumn{6}{l|}{ Organ/Carcass Condemned } \\
\hline Sheep & \multicolumn{7}{|l|}{ Live } & Lung & Heart & Kidney & Carcass \\
\hline Young & 384 & 82 & 29 & 1 & - & - \\
\hline Adult & 98 & 98 & 79 & 4 & - & - \\
\hline Total & 768 & 180 & 108 & 5 & - & - \\
\hline Goats & 99 & 99 & 23 & 3 & - & - \\
\hline Young & 98 & 98 & 66 & 7 & - & - \\
\hline Adult & 768 & 197 & 89 & 10 & - & - \\
\hline Total & $\mathbf{1 5 3 6}$ & $\mathbf{3 7 7}$ & $\mathbf{1 9 7}$ & $\mathbf{1 5}$ & - & - \\
\hline Total & $\mathbf{3}$ &
\end{tabular}

The overall liver condemnation due to parasitic causes was $24.5 \%$ (Stellesia hepatic, cysticercus tenuicollis, fasciola species and hydatid cysts). There was no statically significant differences between sheep and goats $(\mathrm{P}>0.05)$ and also between young and adult age group of both species (table 3 )

Table3. Parasite Causes of Liver Condemnation

\begin{tabular}{|l|l|l|l|l|l|l|}
\hline \multirow{2}{*}{ Abnormalities } & \multicolumn{3}{|l|}{ Sheep } & Goats & \multicolumn{2}{l|}{} \\
\cline { 2 - 7 } & Young & Adult & Total & Young & Adult & Total \\
\hline Fasciola & 20 & 32 & 52 & 13 & 14 & 27 \\
\hline Stellesia Hepatica & 39 & 33 & 72 & 44 & 48 & 92 \\
\hline cysticercus tenuicollis & 17 & 22 & 39 & 38 & 27 & 65 \\
\hline Hydrated cysts & 6 & 11 & 17 & 4 & 9 & 13 \\
\hline Total & $\mathbf{8 2}$ & $\mathbf{9 8}$ & $\mathbf{1 8 0}$ & $\mathbf{9 9}$ & $\mathbf{9 8}$ & $\mathbf{1 9 7}$ \\
\hline
\end{tabular}

Hydatidosis followed by lung worm were the major causes of lung rejection. There was no statistically significant differences between sheep and goats $(\mathrm{P}>0.05)$ but statistically significant difference was observed $(\mathrm{P}<0.05)$ between the young and adult age group of both species (table 4$)$

Table4. Parasite Causes of Lung Condemnation

\begin{tabular}{|l|l|l|l|l|l|l|}
\hline \multirow{3}{*}{ Abnormalities } & \multicolumn{6}{|c|}{ Animal Species } \\
\cline { 2 - 7 } & Sheep & Goats & Total \\
\cline { 2 - 7 } & Young & Adult & Total & Young & Adult & 16 \\
\hline Hydrated cysts & 6 & 18 & 24 & 5 & 16 & 21 \\
\hline Lung worm & 23 & 61 & 84 & 18 & 50 & 68 \\
\hline Total & 29 & 79 & 108 & 23 & 66 & 89 \\
\hline
\end{tabular}

Out of the 15 total hearts condemned due to parasite cause, cysticercus ovis contribute $(0.97 \%)$. There was significant differences between the age groups young and adult $(\mathrm{P}>0.05)$ while no significant difference between the two animals $(\mathrm{P}>0.05)($ able-5). 
Parasitic Cause of Organ and Carcass Condemnation in Small Ruminant Slaughtered at Helmex Abattoir, Debrezeit, Ethiopia

Table5. Causes of Heart Condemnation

\begin{tabular}{|l|l|l|l|l|l|l|}
\hline \multirow{4}{*}{ Abnormalities } & \multicolumn{6}{|c|}{ Animal Species } \\
\cline { 2 - 7 } & Sheep & Goats & Total \\
\cline { 2 - 7 } & Young & Adult & Total & Young & Adult & 10 \\
\hline C. ovis & 1 & 4 & 5 & 3 & 7 & 10 \\
\hline Total & 1 & 4 & 5 & 3 & 7 & \\
\hline
\end{tabular}

\subsection{Assessment of Direct Economic Loss}

Using all the necessary information in the formula set by Ogurinade and Ogurinade (1980) the annual direct economic loss from international and domestic market of organs and carcass at HELMEX abattoir was estimated to be 47,272.5 USD.

Table6. Finding of the Study Used in the Direct Economic Analysis

\begin{tabular}{|c|c|c|c|c|c|}
\hline \multirow[t]{2}{*}{ Organ/Carcass } & \multicolumn{2}{|c|}{$\begin{array}{l}\text { Species of animal } \\
\text { rejection rates }\end{array}$} & \multicolumn{2}{|c|}{$\begin{array}{l}\text { Average annual } \\
\text { slaughter rate }\end{array}$} & \multirow[t]{2}{*}{$\begin{array}{l}\text { Average price of organ/ } \\
\text { carcass on market }\end{array}$} \\
\hline & Sheep (\%) & Goat (\%) & Sheep(n) & Goat(n) & \\
\hline Liver & 24.4 & 25.6 & 30,000 & 40,000 & $2.75 \mathrm{UD} / \mathrm{kg}$ \\
\hline Lung & 14.0 & 11.5 & & & $0.1 \mathrm{ETB}$ \\
\hline Heart & 0.65 & 1.3 & & & $0.1 \mathrm{ETB}$ \\
\hline Kidney & - & & & & $2.75 \mathrm{USD} / \mathrm{kg}$ \\
\hline Carcass & - & & & & $2.75 \mathrm{UD} / \mathrm{kg}$ \\
\hline
\end{tabular}

\section{DiSCUSSION}

Meat inspection is conducted in the abattoir for the purposes of screening and removing animal products with abnormal pathological lesion that are unattractive and unsafe for human consumption. Meat inspection assists to detect meat that could give rise to disease of livestock and prevent the distribution of infected meat that could give rise to disease in animals and human being and to ensure competitiveness of the product in the local and global market (EVA, 2002; Graney et al., 1999; Hinton and Green, 1997, Vanlongestigin, 1993).

In developing countries abattoirs play a major role in providing and serving as sources of information and a references center for diseases prevalence. Alonge and Fasamni (1979) suggested that governments or other program aimed at controlling or eradicating disease across African countries use abattoir survey result in the planning and control of livestock disease.

In the present study thorough post mortem examination was conducted in the abattoir after all the animals in the lair age have passed the ante mortem inspection. The animal to be examined in the lair age at HELMEX export abattoir are not directly bought from the customers in the abattoir but the animals are transported to the abattoir by vehicle after they are congregated in holding pens found in Afar, SNNPR and Oromia regions. The most commonly encountered abnormalities during ante mortem were nasal discharge lameness, localized swelling and poor body condition. Nasal discharge observed were probably due to immune suppression, stress and consequent respiration diseases during transportation and overcrowding in the lair age (Jibat, 2002).

Diseased or animals show sign of abnormality during ante mortem inspection should not be allowed to enter abattoir for slaughter (Teka, 1997).

Postmortem inspection of the carcass of these animals revealed that the swelling were all localized to one area and the lameness was due to trauma to the legs, while being driven to the abattoir. Hence, in both case the affected part were trimmed off and the rest part of the carcass was passed fit for human consumption.

The present study revealed that out of the total 1536 slaughtered small ruminants $377(24.5 \%), 197$ $(12.87 \%, 15(0.97 \%), 0(0)$ and $0(0)$ of liver, lung, heart, kidney and carcass respectively were rejected from market due to their gross abnormalities (table 2). The organs passed for consumption in the HELMEX Export Abattoir are marketed in the Middle east countries based on their requirement, but the majority of the organs, are sold at local market The rejected organs which found pathologically unfit for human consumption are incinerated in the abattoir to break transmission cycle of the diseases. 
During the study, 180(23.4\%) and 197(25.6\%) liver of ovine and caprice, respectively were encountered and rendered the liver to be condemned during the study period are: fasciollosis, Stellesia hepatica, Cysticercus tenuicollis and hydrated cysts

Research conducted by several investigators on ovine fasciollosis prevalence's in different parts of the country revealed 3.6\% in Debre Zeit HELMEX( Jibat, 2006), 40.6 in Gondar (Yimam, 2003), 53.3\% in eastern Gojam (Beyazen, 1995) and 30\% in Ziway (Abdela, 1994) and caprice fasciollosis prevalence's revealed 8.3\% in Debre Zeit HELMEX (Seblewengel, 2007).

In Ethiopia, fasciollosis has been reported to be one of the major diseases problems of livestock industry and exist in almost all regions. However the prevalence rate epidemiology and Fasciola species involved vary significantly with locality. This is attributed mainly due to the variation in the climate and ecological condition (Manyazeual, 1995; Lama et al.,1985; Bahiru and Ephraim, 1979).

Cysticercus tenuicollis is the most important and widely prevalent methacestode recorded in small ruminant slaughtered in the study abattoir. The prevalence of Cysticercus tenuicollis by species was slightly higher in goats (8.4\%) has compared to sheep (5\%). However this difference was not found statistically significant. The result in this study is lower than that reported by other workers. Research conducted by several investigators on ovine Cysticercus tenuicollis prevalence in different part of the country revealed 25.8\% in wolyta (Muktar, 1988), 46.1\% in Dessie (Yilkal, 1989), 37.1\% in Addis Ababa abattoir (Tekylene et al, 1988) and 32.7\% in three export abattoir (ELFORA, Hashim and Luna) by Abdela (2006).

The prevalence of Cysticercus tenuicollis found in goats in this study $(8.4 \%)$ is lower than that reported by other workers, $16.3 \%$ in wolyta (Muktar, 1988) and $34.7 \%$ in three export abattoir (ELFORA, Luna and Hashim) by Abdela (2006, the relatively lower prevalence of Cysticercus tenuicollis recorded in the study could be due to the variation in temperature, environmental condition, the degree of pasture contamination and the way of raising and grazing of these animals, which are may favors the transmission cycle between ruminants and dogs. The age of the animals could also be another factor in this variation. The prevalence by age revealed that slightly higher infection rates was recorded in adult ovine (5.7\% in adult and $4.4 \%$ in young). But the reverse holds true for caprice (9.8\% in young and $8.4 \%$ in adults). These differences in prevalence rate between the age of ovine and caprice are not statistically significance $(\mathrm{P}>0.05)$.

The prevalence of hydrated cyst found in this study was $5.3 \%$ and $4.4 \%$ in sheep and goats respectively. The prevalence rate recorded in this study is less than that reported by other investigator in other abattoir of this country. The prevalence of these workers are $8.7 \%$ ovine and $4.6 \%$ caprice in Gondar (Tamene, 1987), 40.6\% ovine and 70\% caprice in Addis Ababa abattoir (Gemeda, 1988), 16.4\% ovine in Addis Ababa abattoir (Tekylene et al, 1988), 9.3\% ovine and 6.5\% caprice in Hararghe region (Weber, 1987) and 6\% ovine in Wolyta (Muktar, 1988).

The lower prevalence found in both species in the study may be ascribed to the origin of the slaughtered animals, which in majority of cases, is from low land areas where the environmental condition such as high temperature and low humidity exist. The other reason could also be due to the fact that most of the animals presented for slaughtered in this export abattoir are young it is established fact that prevalence of Hydrated cyst

Increase as the age of animal increases (WHO, 1994). There for the highest prevalence rate is expected in older animals. The general trend of age prevalence data was the infection rate increases with age, for the two animal species as a result statistical significance was observed $(\mathrm{P}<0.05)$ between the young and adult of both species.

The prevalence of Cysticercus ovis recorded in the study $(0.65 \%$ and $1.3 \%$ in sheep and goat respectively). There is no enough documented report on this parasite, only reported by Abdela (2006). Therefore, they could not discuss the result of the finding in comparison to other workers in the country due to lack documented information in the subject.

The prevalence of lung worm found in this study was $10.9 \%$ and $8.8 \%$ in sheep and goats respectively. The prevalence of lung worm by species was slightly higher in sheep ( 0.9 ) as compared to goats $(8.8 \%)$. However this difference was not found statistically significant. Similar reports in goats were made in same abattoir $7.5 \%$ in Debre Zeit Hashim abattoir by (Eschew, 2007). The prevalence recorded in this study is higher than that of Eschew. The higher prevalence in this study 
may be due to origin of examined animals and the presence of close association between intermediate host and final host.

The prevalence by age revealed that higher infection rates was recorded in animals with adult age (15.8\% in sheep and 13\% goats) and recorded in animals with young age (5.9\% in sheep and $4.6 \%$ in goats) and these was statistically significant differences was observed $(\mathrm{P}<0.05)$ between the young and adult age group of both species.

The prevalence of Stellesia hepatica found in this study was $9.3 \%$ and $11.9 \%$ in sheep and goats respectively. The prevalence of Stellesia hepatica by species was slightly higher in goats $(11.9 \%)$ and as compared with sheep (9.3\%). However this difference was not statistically significant.

The prevalence of this study is similar with that of other investigators, 9.3\% ovine in Debre Zeit by Jibat(2006).The prevalence of this study on caprice Stellesia hepatica slightly lowers, $12.1 \%$ in Debre Zeit by (Jibat, 2006) and relatively lowers, 44\% in Debre Zeit by Eschew(2007). The lower prevalence may be due the origin of animal examined, where the intermediate host prevalence is lower.

The threat of these parasites that poses to the small ruminants meat industry in Ethiopia is evident due to the present situation of improper disposal of offal's being practiced and free access of condemned organs to stray dogs (Jibat, 2006). This study revealed that in relation to other organs liver and lung are most commonly affected and rejected from international and local market prices and costing to much loss to the livestock industry of the country. The rejection rate of kidney, heart and carcass was however not significant.

The economic losses incurred during this study as a result of condemnation or rejection of edible organs of ovine and caprice specious was estimated approximately about million ETB per annum in HELMEX export abattoir from international and domestic market.

\section{CONCLUSON AND RECOMMENDATION}

According the result of present study fasciollosis, Hydatidosis Cysticercus tenuicollis, Stellesia hepatica and lung worm are the most and major causes for respective organs to be rejected and this result extensive financial wastes about 47272.5USD. The proper management practices of animals on farm or at home and improper disposal or handing of offal's in control of parasitic diseases result in severe economic losses and consequently exclude the country from attractive international market there by greatly redacting the country; foreign exchange earnings. In line with finding of this study the following recommendation are forwarded so as to resolve and reduces the significant economic loss incurred.

- Enhances the awareness of the animal attendants, farmers, customers, abattoir works and butchers about the public health significances of the disease, and proper disposal of condemned offal's by giving them country wide education in collaboration with the government and prohibit the sale of contaminated offal's and condemned head as pet food

- Government should be prohibit backyard slaughtering in different localities and encourage investors who have the capacity to build modern abattoir in different area of the country.

- Dog owners should be regularly deform their animals with Anthelmintics to break perfect life cycle of parasites that might have public health importance.

- Cooperation between veterinary and medical personnel is important in order to control most meat born zoometric diseases and thus provide safe and wholesale meat to the consumers

\section{REFERENCES}

Abebe, G. (1995) current status of veterinary education and animal health research in Ethiopia. In Veterinary medicine impact of human health and nutrition in Africa. Proceeding of an international conference. ILRI, Addis Ababa. $\mathrm{P}_{\mathrm{p}}$. 133-138.

Abdela, A. (2006). Methacestode of small ruminants of three export abattoirs (ELFORA, HELMEX and Luna), MSc thesis, FVM, AAU.P. $33-45$.

Abdella, A. (1994). Prevalence's of ovine and bovine fasciollosis; a preliminary survey around Ziway, show region DVM thesis, FVM, AAU, Debre Zeit $\mathrm{P}_{\mathrm{P}} .16$ 
Alonge, D.D. and Fasamni, E.F.(1979). A survey of ablation data in southern Nigeria, Trop. Anim. Hath prod. 11: 57-62.

Asefa, M.(2005). Parasitic causes of carcass/organ condemnation at Asella Municipality Abattoir. Degre Zeit: FVM, AAU, DVM thesis $P_{P}$. 6-7.

Bahiru, G. and Ephraim. M. (1979). A preliminary survey of bovine fasciollosis in Ethiopia. Eth. J. Agri. Sci. $\mathrm{P}_{\mathrm{P}}$. 5-12.

Beyazen, C. (1995). Preliminary study on epidemiology of fasciollosis in Eastern Gojam region, Ethiopia. DVM thesis, FVM, AAU. Debre Zeit.

EVA (2002). Animal health and poverty production strategies. Proceeding of the $6^{\text {th }}$ annual conference of EVA, Addis Ababa, and Ethiopia $P_{P .} 1$

FAO (1994). Meat inspection manual for developing countries. Rome, Italy.

Fletcher, I. and Zelalem, A. (1991). Small ruminant productivity in central Ethiopia mixed farming system, institute of agricultural research proceeding $4^{\text {th }}$ national livestock improvement conference. Addis Ababa, Ethiopia.

Gatenby, R.M (1991). Sheep. The tropical agriculturist, London and stoke basing Macmillan education Ltd, Acct, $\mathrm{P}_{\mathrm{P}}$. 6-10.

Gemeda, B.(1988):Preliminary study on Hydatidosis in livestock (cattle, sheep goats and pigs)slaughtered at Addis Ababa abattoir. FVM, Debre Zeit, Ethiopia.

Hinton, H.M and Greed L.E (1997). Meat inspector whither Goes thou university of Bristol, Langford, UK. The veterinary journal 154(2): 91-92.

Jacob, L. (1979) Seminar for animal health officials. Ministry of agriculture and settlement, Animal and fishers authority. Addis Ababa, Ethiopia.

Jembere, S. (2002). A survey of causes of organ/ carcass condemnation in slaughter cattle at Nazaret abattoir. Debre Zeit: FVM, AAU, DVM Thesis. P. 20.

Jibat, T. (2006). Causes of organ and carcass condemnation in small ruminant slaughtered at Debre Zeit HELMEX abattoir. DVM thesis, FVM, AAU, Debre Zeit, Ethiopia.

Jobre, Y. Lob ago, F. Tiruneh, R. Abebe, G. and Diarchies, ph. (1996). Hydatidosis in three selected region in Ethiopia: An assessment trial on its prevalence's, economic and public health importance. Rev. Vet. P. 797-804.

LMA.(2001). Livestock marketing authority, A brief baseline information on Ethiopian livestock resources base and its trade. Addis Ababa, Ethiopia. $\mathrm{P}_{\mathrm{P} .}$ 1-9.

Manyazeual, A.A. (1995). A study on bovine fasciollosis in western Ethiopia Parasitology research in Africa Babodioulasso, Burcinafaso $\mathrm{P}_{\mathrm{P}}$ 203-207.

Muktar, R. (1988): Preliminary survey of gastro- intestinal helminthes in dogs, cysticercus tenicullolis in sheep and goats, Hydatidosis in sheep, goats and cattle, at walayta Awraja. DVM thesis, AAU. FVM, Debre Zeit, Ethiopia.

Nit, A.N and Alonge, D.O (1987). An economic survey of abattoir data in Fake division of south wet province, Cameron. Bull. Annul. Hath. Prod. Afr. 35(3): P. 239-242.

NMSA. (2003). National meteorology service agency. Addis Ababa, Ethiopia

Ogurinade, A. and Ogurinade, B.I. (1980). Economic importance's of Fasciollosis in Nigeria Trop. Animal. Hath prods. $\mathrm{P}_{\mathrm{P} .}$ 155-159.

Radostits, O.M. Gay, C.C, Blood, D.C. and Hinchcliff, K.W.(2000). Veterinary medicine, A text book of diseases of castle, sheep, goats, pig and horses. $9^{\text {th }}$ end London, Bailliere.

Sirank, A. (1991). Causes of organ condemnation in Bahir Dar Abattoir. Proceeding of the $4^{\text {th }}$ national livestock improvement conference. Institute of Agricultural research, Addis Ababa, Ethiopia.

STATA (2001). Inter cooled STATA 7.0 (State corp./ 1984-2001, college station, Texas, 77845).

Steele, M. (1996). Goats: The Tropical Agriculturists, London and Basingstoke, Macmillan Education Ltd. Acct. $\mathrm{P}_{\mathrm{P}}$ 79-83.

Tamene, M. (1986): Preliminary study of Echinococcosis in livestock in Gondar. DVM thesis, AAU, FVM, Debrezeit Ethiopia. 
Taka, G.(1997). Food Hygiene principle and mofrod of food borne diseases control with special references to Ethiopia. FVM, AAU $P_{P .}$ 110-112.

Tekleye, B.J Mukasa- Mugerwa, E.J Kasali, O.B.(1988): The prevalence's of cysticercoids and Hydatidosis in Ethiopia sheep. Veterinary Parasitology, 28:267-270.

Van Longtentijin J.G. (1993). Integrated quality meat safety: A new approach. Meat Focus international (2) pp. 123-128.

Wubet, M. (1987): A preliminary study of Echinococcosis in Hararghe region. DVM thesis, AAU, FVM, Debre Zeit Ethiopia.

Yilkal, A. (1989): Hydatidosis in cattle, sheep, pigs; cysticercus tenuicollis in sheep around Dessie and the efficacy of Hageman Abyssinia (koso) on Tania hydatigena DVM thesis, AAU, FVM, Debre Zeit, Ethiopia.

Yimam, M. (2003). Major cause of organ condemnation in ruminants slaughtered at Gondar Abattoir, North Western Ethiopia, Debre Zeit: FVM. AAU, DVM Thesis. Pp. 1-9. 